\title{
A New Validated Stability Indicating RP-HPLC Method for Simultaneous Estimation of Pyridoxine Hydrochloride and Meclizine Hydrochloride in Pharmaceutical Solid Dosage Forms
}

\author{
Md. Saddam Nawaz \\ Quality Assurance Department, ACI Ltd., Narayanganj 1400, Bangladesh \\ Correspondence should be addressed to Md. Saddam Nawaz; nawazdu@gmail.com
}

Received 1 February 2013; Accepted 28 March 2013

Academic Editor: Irene Panderi

Copyright (c) $2013 \mathrm{Md}$. Saddam Nawaz. This is an open access article distributed under the Creative Commons Attribution License, which permits unrestricted use, distribution, and reproduction in any medium, provided the original work is properly cited.

A simple, specific, accurate, precise stability indicating reversed-phase high-performance liquid chromatographic (RP-HPLC) method was developed and validated for the simultaneous determination of pyridoxine hydrochloride (PYH) and meclizine hydrochloride (MEH). An isocratic separation of PYH and MEH were achieved on C 18, $250 \times 4.6 \mathrm{~mm}$ ID, $5 \mu \mathrm{m}$ particle size columns at column oven temperature $37^{\circ} \mathrm{C}$ with a flow rate of $0.5 \mathrm{~mL} \mathrm{~min}^{-1}$ and using a diode array detector to monitor the detection at $254 \mathrm{~nm}$. The mobile phase consisted of buffer : acetonitrile : trifluoroacetic acid at a ratio of $30: 70: 0.1(\mathrm{v} / \mathrm{v})$. The retention times of PYH and MEH was found to be 5.25 and $10.14 \mathrm{~min}$, respectively. Suitability, specificity, linearity, accuracy, precision, stability, and sensitivity of this method for the quantitative determination of the drugs were proved by validation in accordance with the requirements laid down by International Conference on Harmonization (ICH) Q2 (R1) guidelines. The proposed method is reliable and robust and can be used as quality control tool for the estimation of these drugs in combined pharmaceutical solid dosage forms.

\section{Introduction}

Pyridoxine hydrochloride (PYH) is chemically 3, 4-pyridinediacetonitrile, 5-hydroxy-6-methyl, hydrochloride (Figure 1). It is a water-soluble vitamin and involved principally in amino acid, carbohydrate, and fat metabolism [1]. It is also required for the formation of hemoglobin [2]. Meclizine hydrochloride (MEH) (Figure 2) is often used as "meclozine" which is chemically 1-[(4-Chlorophenyl)(phenyl)methyl]-4(3-methylbenzyl)piperazine, dihydrochloride monohydrate, a first-generation antihistamine of the piperazine class. Meclizine is effective in inhibiting the symptoms of motion sickness, such as nausea, vomiting, and dizziness. PYH is official in IP [3], BP [4, 5], and USP [6], and MEH is also official in BP $[4,5]$ and USP [6]. The pharmacopeias describe potentiometric, spectrophotometrics and HPLC method for the determination of PYH and $\mathrm{MEH}$ individually from the bulk and tablet dosage form. No reversed-phase high-performance liquid chromatography (RP-HPLC) method is reported in pharmacopeias for the simultaneous estimation of PYH and $\mathrm{MEH}$ from their combined formulation, though there are various methods for the determination of PYH and MEH by spectrophotometric [7-12], voltammetric [13], HPLC [1416], electrophoresis [17], GLC [18], HPTLC [19], and TLC [20] methods in different pharmaceutical dosages forms. The present work describes the development and validation of stability indicating RP-HPLC method, which can quantify PYH and MEH simultaneously in pharmaceutical solid dosage form. The confirmation of the applicability of this developed method was validated according to the International Conference on Harmonization (ICH) Q2 (R1) [21].

\section{Experimental}

2.1. Reagents and Chemicals. Pure standards of PYH and MEH were obtained from Jianxi Sentai Pharmaceutical Co. Ltd., China, and M/S FDC Ltd., India, having purities of $99.23 \%$ and $99.10 \%$, respectively. The formulated film-coated tablets (pyrimac tablet) were prepared from Advanced Chemical Industries (ACI) Limited, Narayanganj, 


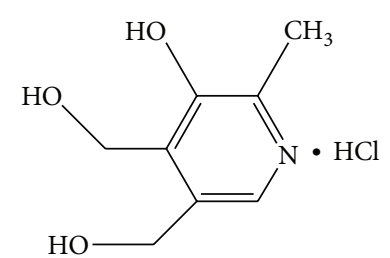

FIgURE 1: Chemical structure of pyridoxine hydrochloride.<smiles>Cc1cccc(CN2CCN(C(c3ccccc3)c3ccc(Cl)cc3)CC2)c1</smiles>

FIGURE 2: Chemical structure of meclizine hydrochloride.

Bangladesh. Each tablet contains combined $50 \mathrm{mg}$ pyridoxine hydrochloride and $25 \mathrm{mg}$ meclizine hydrochloride (based on $100 \%$ potency) as active ingredients, as well as microcrystalline cellulose (avicel PH 102), sodium starch glycolate (SSG), Colloidal silicon dioxide (aerosil-200), croscarmellose sodium, Allura red lake, and magnesium stearate as excipients in addition to Opadry II 85G54426 pink as coating material.

Acetonitrile HPLC grade (Scharlau), anhydrous sodium dihydrogen phosphate (Scharlau), phosphoric acid AR grade, (Merck) and trifluoroacetic acid (Fisher Scientific) were used for analytical purposes. Ultrapure water was used to prepare the mobile phase. Ultrapure water was prepared by using Labconco WaterPro PS purification system.

2.2. Instrument and Chromatographic Condition. Chromatographic separation was achieved by using Shimzadu prominence LC-20AD high-performance liquid chromatography, equipped with degasser PGU-20A 5, variable wavelength programmable diode array detector SPD-M20A, autosampler SIL-20 AC HT, and column oven CTO-10 A5 VP. ProntoSIL $\mathrm{C} 18,250 \times 4.6 \mathrm{~mm}$ ID, $5 \mu \mathrm{m}$ particle size was used as the stationary phase. The column temperature was kept at $37^{\circ} \mathrm{C}$, and the mobile phase flow rate was maintained at $0.5 \mathrm{~mL} \mathrm{~min}^{-1}$. The detection was monitored at $254 \mathrm{~nm}$. The injection volume was $20 \mu \mathrm{L}$, and the run time was $13 \mathrm{~min}$ for each injection. Other instruments such as $\mathrm{pH}$ meter (Jenway 3510), electronic weighing balance (Mettler-Toledo), and ultrasonic bath (Clifton) were also used.

Dionex ultimate 3000 series HPLC and Hichrom C18, $250 \times 4.6 \mathrm{~mm}$ ID, $5 \mu \mathrm{m}$ particle size column were used for ruggedness study.

2.2.1. Mobile Phase. A mixture of buffer, acetonitrile, and trifluoroacetic acid (TFA) at a ratio of $30: 70: 0.1(\mathrm{v} / \mathrm{v})$ was prepared. The resulting solution was sonicated for $5 \mathrm{~min}$ using ultrasonic bath, and finally the mixture was filtered using $0.2 \mu \mathrm{m}$ membrane filter.

2.2.2. Preparation of Buffer for Mobile Phase. $12 \mathrm{~g}$ of anhydrous sodium dihydrogen phosphate was dissolved in $900 \mathrm{~mL}$ of ultrapure water. Then the $\mathrm{pH}$ was adjusted to 3.0 with orthophosphoric acid and volumed up to $1000 \mathrm{~mL}$ with ultrapure water and sonicated for 5 min using ultrasonic bath then filtered through $0.2 \mu \mathrm{m}$ membrane filter.

2.2.3. Diluting Solution. A mixture of buffer, acetonitrile, and trifluoroacetic acid (TFA) at a ratio of $35: 65: 0.1(\mathrm{v} / \mathrm{v})$ was used as the diluents.

2.2.4. Standard Preparation (at Nominal Concentration). $\mathrm{PYH}$ and $\mathrm{MEH}$ working standards were accurately weighed and were transferred into a clean and dry $100 \mathrm{~mL}$ standard volumetric flask and dissolved to prepare $0.50 \mathrm{mg} \mathrm{mL}^{-1}$ and $0.25 \mathrm{mg} \mathrm{mL}^{-1}$ concentrations of PYH and MEH stock solution, respectively, with the diluting solution and finally volumed up to the mark. The solution was sonicated for $5 \mathrm{~min}$ using ultrasonic bath and then filtered through $0.2 \mu \mathrm{m}$ disk filter.

2.2.5. Sample Preparation. Twenty tablets (pyrimac tablet) were crushed and then powdered finely. To prepare assay sample solution, powdered sample equivalent to $50 \mathrm{mg}$ pyridoxine hydrochloride and $25 \mathrm{mg}$ meclizine hydrochloride was weighed accurately and taken into $100 \mathrm{~mL}$ volumetric flask. About $40 \mathrm{~mL}$ of diluting solution was added and shaken thoroughly to extract the drug from the excipients and then sonicated for $5 \mathrm{~min}$ to complete dissolution of drug. The solution was allowed to cool at room temperature and then volume up to the mark. The solution was filtered through Whatman filter paper (no. 42) and then finally filtered through $0.2 \mu \mathrm{m}$ disk filter.

\subsection{Method Validation Parameters}

2.3.1. System Suitability. To assess system suitability of the method, the repeatability, theoretical plates, tailing factor, and retention time of six replicate injections of standard $\mathrm{PYH}$ and $\mathrm{MEH}$ of concentrations $0.50 \mathrm{mg} \mathrm{mL}^{-1}$ and $0.25 \mathrm{mg} \mathrm{mL}^{-1}$, respectively, were used, and the percent relative standard deviation (\%RSD) values were calculated in each case.

2.3.2. Linearity. The linearity of the method was determined at five different concentration levels (80\%, 90\%, 100\%, 110\%, and $120 \%$ ) ranging from 0.395 to $0.592 \mathrm{mg} \mathrm{mL}^{-1}$ of $\mathrm{PYH}$ and $0.203-0.304 \mathrm{mg} \mathrm{mL}^{-1}$ of $\mathrm{MEH}$, respectively. The linearity was evaluated by peak area versus concentration, which was calculated by the least-square regression analysis, and the respective regression equation was computed.

2.3.3. Specificity. The specificity of the developed RP-HPLC method for the determination of $\mathrm{PYH}$ and $\mathrm{MEH}$ in bulk 


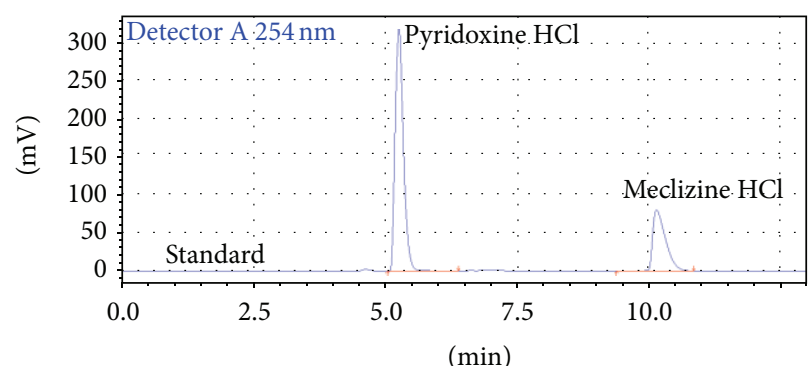

(a)

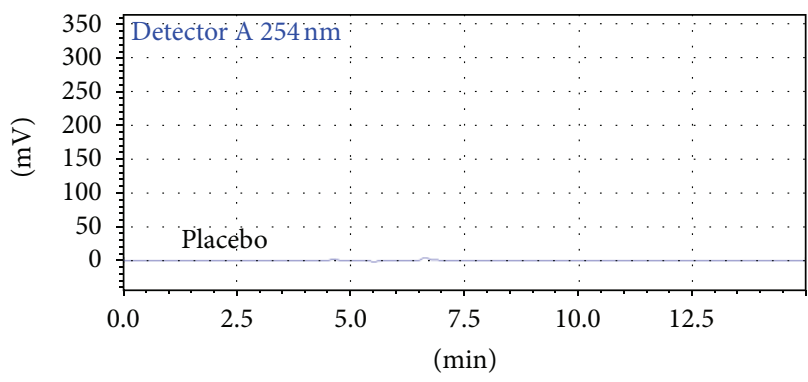

(c)

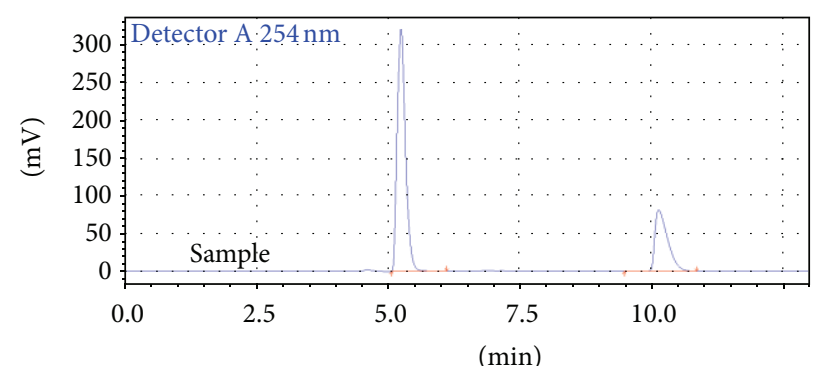

(b)

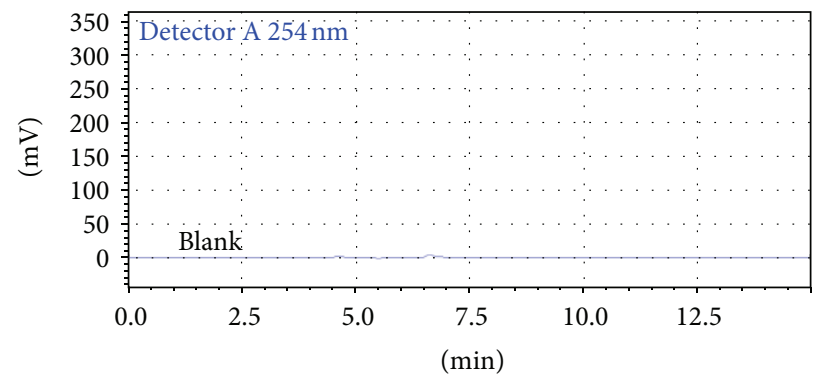

(d)

FIgURE 3: RP-HPLC chromatogram of blank, placebo, tablet sample, and standard of pyridoxine $\mathrm{HCl}$ and meclizine $\mathrm{HCl}$.

drug and pharmaceutical preparation (pyrimac tablet) was investigated by chromatographic analysis of the following.

Noninterference of Placebo. To check the noninterference of placebo, placebo solution was prepared in the same way of the sample solution in the presence of all inactive ingredients of the pyrimac tablet formulation but without PYH and MEH.

Degradation Studies. Degradation studies were carried out under acid hydrolysis, alkali hydrolysis, oxidation, and reduction. One formulated full tablet was taken as a sample for degradation study. For acid hydrolysis $5 \mathrm{~mL}$ of $0.1 \mathrm{~N} \mathrm{HCl}$ was added to sample, kept for 8 hours (at $25 \pm 2^{\circ} \mathrm{C}$ ), then neutralized with $0.1 \mathrm{~N} \mathrm{NaOH}$ and volumed up to mark with diluent. For alkali hydrolysis $5 \mathrm{~mL}$ of $0.1 \mathrm{~N} \mathrm{NaOH}$ was added to sample, kept for 8 hours (at $25 \pm 2^{\circ} \mathrm{C}$ ), then neutralized with $0.1 \mathrm{~N} \mathrm{HCl}$ and made to volume with diluent. A $10 \% \mathrm{H}_{2} \mathrm{O}_{2}$ solution and $10 \%$ sodium bisulphate solution were used for oxidative and reductive study, consecutively. The final solution was injected for assay analysis, and the presence of interfering peak(s) eluted at or near the retention time of $\mathrm{PYH}$ and $\mathrm{MEH}$ was also checked. All determinations were conducted in triplicate. The Peak purity tool was used to check the purity of the test solution.

2.3.4. Accuracy. Accuracy was carried out for drug-matrix solutions. Accuracy parameter was determined by the recovery test, which consisted of adding known amounts of PYH and $\mathrm{MEH}$ in to the placebo sample solutions. This test was conducted by three different concentrations $(80,100$, and $120 \%$ ) of test sample in three replicate sample preparations, and the percent recoveries (mean $\pm \%$ RSD of three replicates) of PYH and $\mathrm{MEH}$ in drug-matrix form were calculated.
TABLE 1: Chromatographic characteristics of system suitability study.

\begin{tabular}{lcc}
\hline Parameters & \multicolumn{2}{c}{ Value $($ Mean \pm RSD) } \\
& PYH & MEH \\
\hline Peak area & $3485193 \pm 0.08$ & $1347970 \pm 0.08$ \\
Tailing factors & $1.29 \pm 1.06$ & $1.53 \pm 0.45$ \\
Retention time & $5.25 \pm 0.02$ & $10.14 \pm 0.04$ \\
Theoretical plates & $5198 \pm 0.10$ & $8127 \pm 0.08$ \\
\hline
\end{tabular}

${ }^{*}$ Mean and \%RSD of six replicate.

TABLE 2: Parameters of regression analysis.

\begin{tabular}{lcc}
\hline Parameters & PYH & MEH \\
\hline Linearity range $\left(\mathrm{mg} \mathrm{mL}^{-1}\right)$ & $0.395-0.592$ & $0.203-0.304$ \\
Correlation coefficient & 0.999 & 1.000 \\
$\% Y$ intercept & 1.61 & 0.17 \\
\hline
\end{tabular}

The accuracy was also evaluated by linear regression analysis and computed.

2.3.5. Precision. Precision of the method was studied by analysis of three replicates of standard solution in three different concentrations $(80,100$, and $120 \%)$. It was demonstrated by repeatability (intraday precision) and intermediate precision (interday precision) of standard solutions. The results were expressed as \%RSD of the measurements.

2.3.6. Stability of Solution. The solution stability is tested by allowing the prepared drug matrix tested sample to stand exposed to room light and ambient room temperature for 
TABLE 3: Results showing different degradative outcomes.

\begin{tabular}{llcccc}
\hline \multirow{2}{*}{ Parameters } & $\begin{array}{l}\text { Pyrimac tablet }\left(\mathrm{mg} \mathrm{tab}^{-1}\right) \\
\text { PYH }\end{array}$ & MEH & Assay at forced condition $\left(\mathrm{mg} \mathrm{tab}^{-1}\right)^{*}$ & \multicolumn{2}{c}{ Percent of degradation $(\%)$} \\
PYH & MEH & & PYH \\
\hline Normal & 50.00 & 25.00 & & & \\
\hline Acidic & & $49.39 \pm 0.10$ & $23.84 \pm 0.09$ & 1.22 & 4.64 \\
Alkaline & & $49.40 \pm 0.08$ & $23.75 \pm 0.11$ & 1.20 & 5.00 \\
Oxidation & & $48.11 \pm 0.06$ & $23.85 \pm 0.07$ & 3.78 & 4.60 \\
Reduction & & $49.68 \pm 0.12$ & $23.90 \pm 0.15$ & 0.64 & 4.40 \\
\hline
\end{tabular}

${ }^{*}$ Mean of three replicate, tab: Tablet.

TABLE 4: Accuracy studies of PYH and MEH in drug-matrix solutions.

\begin{tabular}{|c|c|c|c|c|c|c|}
\hline & $\begin{array}{l}\text { Amount added } \\
\left(\mathrm{mg} \mathrm{mL}^{-1}\right)\end{array}$ & Peak area & $\begin{array}{l}\text { Amount recovered } \\
\left(\mathrm{mg} \mathrm{mL}^{-1}\right)\end{array}$ & $\%$ Recovery & $\begin{array}{c}\text { \% Recovery } \\
(\text { mean } \pm \text { RSD })\end{array}$ & $\begin{array}{c}\text { Over all } \\
\text { (mean } \pm \% \text { RSD) }\end{array}$ \\
\hline \multirow{9}{*}{ PYH } & 0.395 & 2804505 & 0.392 & 99.24 & \multirow{3}{*}{$100.85 \pm 1.38$} & \multirow{9}{*}{$100.32 \pm 1.06$} \\
\hline & 0.395 & 2805301 & 0.402 & 101.65 & & \\
\hline & 0.395 & 2804670 & 0.402 & 101.65 & & \\
\hline & 0.494 & 3481689 & 0.497 & 100.71 & \multirow{3}{*}{$100.57 \pm 0.33$} & \\
\hline & 0.494 & 3487433 & 0.495 & 100.20 & & \\
\hline & 0.494 & 3485039 & 0.498 & 100.81 & & \\
\hline & 0.592 & 4181905 & 0.595 & 100.51 & \multirow{3}{*}{$99.55 \pm 1.02$} & \\
\hline & 0.592 & 4181507 & 0.590 & 99.66 & & \\
\hline & 0.592 & 4183455 & 0.583 & 98.48 & & \\
\hline \multirow{9}{*}{$\mathrm{MEH}$} & 0.203 & 1084674 & 0.207 & 101.88 & \multirow{3}{*}{$101.76 \pm 0.17$} & \multirow{9}{*}{$100.81 \pm 1.01$} \\
\hline & 0.203 & 1084350 & 0.206 & 101.64 & & \\
\hline & 0.203 & 1085947 & 0.207 & 101.88 & & \\
\hline & 0.252 & 1345809 & 0.253 & 100.38 & \multirow{3}{*}{$100.00 \pm 0.33$} & \\
\hline & 0.252 & 1342589 & 0.252 & 99.81 & & \\
\hline & 0.252 & 1348349 & 0.252 & 99.81 & & \\
\hline & 0.304 & 1624589 & 0.308 & 101.41 & \multirow{3}{*}{$100.63 \pm 1.21$} & \\
\hline & 0.304 & 1623470 & 0.308 & 101.25 & & \\
\hline & 0.304 & 1625347 & 0.302 & 99.22 & & \\
\hline
\end{tabular}

three consecutive days. The sample is to be assayed daily and compared to freshly prepared standard solutions.

2.3.7. Sensitivity. For sensitivity study the limit of detection (LOD) and limit of quantitation (LOQ) were estimated by determination of signal-noise ratio. The LOD $(\alpha=3.3)$ and LOQ $(\alpha=10)$ of the proposed method were calculated using the following equation:

$$
A=\alpha \times C \times \frac{N}{S},
$$

where $A$ is LOD or LOQ, $C$ is the concentration in ppm, and $N / S$ is the signal-noise ratio.

2.3.8. Ruggedness. Ruggedness of the current method was determined by analyzing six assay sample solutions of pyrimac tablet by different instrument, column, and two analysts in the same laboratory to check the reproducibility of the test result.
2.3.9. Robustness. To determine the robustness of the current method, the effect of flow rate was studied at 0.48 and $0.52 \mathrm{~mL} \mathrm{~min}^{-1}$ instead of $0.5 \mathrm{~mL} \mathrm{~min}^{-1}$. The effect of column temperature was studied at 35 and $39^{\circ} \mathrm{C}$ instead of $37^{\circ} \mathrm{C}$. The effect of mobile phase composition was assessed at (buffer : $\mathrm{ACN}=31.3: 68.7, \mathrm{v} / \mathrm{v}$ ) and (buffer $: \mathrm{ACN}=28.7: 71.3, \mathrm{v} / \mathrm{v}$ ) instead of (buffer: ACN $=30: 70, \mathrm{v} / \mathrm{v}$ ). The effect of wavelength change was studied at $252 \mathrm{~nm}$ and $256 \mathrm{~nm}$ instead of at $254 \mathrm{~nm}$.

\section{Results and Discussion}

\subsection{Method Validation}

3.1.1. System Suitability. The results (Mean \pm \%RD of six replicates) of the chromatographic parameters (Table 1) indicate the good performance of the system.

3.1.2. Linearity. The peak area was dynamic-linear in the concentration ranges of $0.395-0.592 \mathrm{mg} \mathrm{mL}^{-1}$ for $\mathrm{PYH}$ and 
TABLE 5: Intra-day and inter-day precision of the method.

\begin{tabular}{|c|c|c|c|c|c|c|}
\hline & Sample Conc. (\%) & $\begin{array}{c}\text { Peak area } \\
(\text { day } 1)\end{array}$ & $\begin{array}{c}\text { Peak Area } \\
(\text { Mean } \pm \% \text { RSD })\end{array}$ & $\begin{array}{c}\text { Peak area } \\
\text { (day 2) }\end{array}$ & $\begin{array}{c}\text { Peak Area } \\
(\text { Mean } \pm \% \text { RSD })\end{array}$ & $\begin{array}{c}\text { Overall } \\
(\text { Mean } \pm \% \text { RSD })\end{array}$ \\
\hline \multirow{9}{*}{ PYH } & \multirow{3}{*}{80} & 2802395 & \multirow{3}{*}{$2803478 \pm 0.04$} & 2804067 & \multirow{3}{*}{$2804395 \pm 0.01$} & \multirow{3}{*}{$2803937 \pm 0.03$} \\
\hline & & 2803486 & & 2804588 & & \\
\hline & & 2804553 & & 2804530 & & \\
\hline & \multirow{3}{*}{100} & 3484270 & \multirow{3}{*}{$3485861 \pm 0.05$} & 3485121 & \multirow{3}{*}{$3486142 \pm 0.04$} & \multirow{3}{*}{$3486001 \pm 0.04$} \\
\hline & & 3487551 & & 3487734 & & \\
\hline & & 3485761 & & 3485570 & & \\
\hline & \multirow{3}{*}{120} & 4181755 & \multirow{3}{*}{$4182542 \pm 0.04$} & 4180232 & \multirow{3}{*}{$4181749 \pm 0.04$} & \multirow{3}{*}{$4182145 \pm 0.04$} \\
\hline & & 4181438 & & 4181345 & & \\
\hline & & 4184432 & & 4183670 & & \\
\hline \multirow{9}{*}{$\mathrm{MEH}$} & \multirow{3}{*}{80} & 1084378 & \multirow{3}{*}{$1084599 \pm 0.02$} & 1084421 & \multirow{3}{*}{$1084530 \pm 0.01$} & \multirow{3}{*}{$1084565 \pm 0.02$} \\
\hline & & 1084566 & & 1084666 & & \\
\hline & & 1084854 & & 1084502 & & \\
\hline & \multirow{3}{*}{100} & 1346372 & \multirow{3}{*}{$1346558 \pm 0.06$} & 1345207 & \multirow{3}{*}{$1345681 \pm 0.04$} & \multirow{3}{*}{$1346120 \pm 0.06$} \\
\hline & & 1345756 & & 1345391 & & \\
\hline & & 1347547 & & 1346445 & & \\
\hline & \multirow{3}{*}{120} & 1625634 & \multirow{3}{*}{$1624784 \pm 0.08$} & 1623245 & \multirow{3}{*}{$1623586 \pm 0.04$} & \multirow{3}{*}{$1624185 \pm 0.07$} \\
\hline & & 1623340 & & 1623167 & & \\
\hline & & 1625378 & & 1624345 & & \\
\hline
\end{tabular}

TABLE 6: Stability of analytical sample solution.

\begin{tabular}{lccc}
\hline \multirow{2}{*}{ Day } & Room Temperature & \multicolumn{2}{c}{ \% Recovery $^{*}$} \\
& $\left({ }^{\circ} \mathrm{C}\right)$ & PYH & MEH \\
\hline 1 & $25 \pm 2$ & 100.94 & 100.46 \\
2 & $25 \pm 2$ & 100.17 & 99.65 \\
3 & $25 \pm 2$ & 96.67 & 99.00 \\
\hline
\end{tabular}

${ }^{*}$ Mean of three replicates.

0.203-0.304 $\mathrm{mg} \mathrm{mL}^{-1}$ for $\mathrm{MEH}$, respectively. Highly significant correlation coefficient $\left(R^{2}\right)$ demonstrated the linearity of the method (Table 2).

3.1.3. Specificity. The chromatograms of blank, placebo, test sample, and standard were used to justify the specificity of target analyte. The method was specific since excipients in the formulation did not interfere in the estimation of $\mathrm{PYH}$ and MEH (Figure 3).

The samples submitted to acidic and alkaline condition showed significant alteration in the peak area, and also there was no detectable degradation peak(s). Similarly, during oxidative and reductive hydrolysis study, degradation peak(s) was not found. In every case the peak purity was $99.99 \%$. The results acquired from peak purity tool confirmed that the active components' peak response was pure proving no other substances in the same retention time. Percent of degradation is mainly $3.78 \%$ for PYH during oxidation study as well as $4.64 \%$ for $\mathrm{MEH}$ in acidic condition (Table 3).
3.1.4. Accuracy. The results were expressed as percent recoveries of the particular components in the samples. The overall results of percent recoveries (mean $\pm \% \mathrm{RSD}$ ) of drug-matrix solutions are indicating good accuracy of the proposed RPHPLC method (Table 4). Correlation coefficient $R^{2}=0.999$ and 0.999 established excellent accuracy for the active ingredients PYH and MEH, respectively.

3.1.5. Precision. The values of $\%$ RSD for intraday and interday variation were found very well and within $2 \%$ limit, indicating that the current method is repeatable (Table 5).

3.1.6. Stability of Solution. In the stability study, the retention time remained unchanged till third day, but peak area of PYH and $\mathrm{MEH}$ deviated at third day by more than $2.0 \%$ from initial. This indicates that both solutions were stable for at least 48 hours, which was sufficient to complete the analytical procedure (Table 6).

3.1.7. Sensitivity. The LOD and LOQ by the proposed method were found for PYH $1.90 \mathrm{ppm}$ and $5.74 \mathrm{ppm}$ as well as for MYH 3.75 ppm and 11.35 ppm, respectively.

3.1.8. Ruggedness. The results (\% of Recovery \pm RSD) of six assay samples are indicating the ruggedness of the current method (Table 7).

3.1.9. Robustness. The effects of robustness study under different altered conditions of this proposed method are 
TABLE 7: Ruggedness of the method.

\begin{tabular}{|c|c|c|c|c|c|}
\hline \multirow[b]{2}{*}{$\begin{array}{l}\text { Amount of } \\
\text { PYH } \\
\left(\mathrm{mg} \mathrm{tab}^{-1}\right)\end{array}$} & \multirow[b]{2}{*}{$\begin{array}{l}\text { Amount of MEH } \\
\left(\mathrm{mg} \mathrm{tab}^{-1}\right)\end{array}$} & \multicolumn{2}{|c|}{ Analyst 1 , instrument 1 , column 1} & \multicolumn{2}{|c|}{ Analyst 2 , instrument 2 , column 2} \\
\hline & & $\begin{array}{l}\text { Amount found PYH } \\
\left(\mathrm{mg} \mathrm{tab}^{-1}\right)(\text { Mean } \\
\pm \% \mathrm{RSD})^{*}\end{array}$ & $\begin{array}{l}\text { Amount found MEH } \\
\left(\mathrm{mg} \mathrm{tab}^{-1}\right)(\text { Mean } \\
\pm \% \mathrm{RSD})^{*}\end{array}$ & $\begin{array}{l}\text { Amount found PYH } \\
\left(\mathrm{mg} \mathrm{tab}^{-1}\right)(\text { Mean } \\
\pm \% \mathrm{RSD})^{*}\end{array}$ & $\begin{array}{l}\text { Amount found MEH } \\
\left(\mathrm{mg} \mathrm{tab}^{-1}\right)(\text { Mean } \\
\pm \% \mathrm{RSD})^{*} \\
\end{array}$ \\
\hline 50 & 25 & $50.53 \pm 0.3$ & $25.63 \pm 0.3$ & $50.97 \pm 0.04$ & $25.60 \pm 0.50$ \\
\hline
\end{tabular}

${ }^{*}$ Mean of six replicates.

TABLE 8: Robustness of the method.

\begin{tabular}{|c|c|c|c|c|c|}
\hline \multirow{2}{*}{ Parameters } & \multirow{2}{*}{ Actual Variance } & \multicolumn{2}{|c|}{ Amount added $\left(\mathrm{mg} \mathrm{mL}^{-1}\right)$} & \multicolumn{2}{|c|}{$\%$ Recovery $(\text { Mean } \pm \% \text { RSD })^{*}$} \\
\hline & & PYH & $\mathrm{MEH}$ & PYH & $\mathrm{MEH}$ \\
\hline \multirow{2}{*}{ Flow Rate } & $0.48 \mathrm{~mL} \mathrm{~min}^{-1}$ & 0.5 & 0.25 & $100.55 \pm 0.33$ & $100.04 \pm 0.04$ \\
\hline & $0.52 \mathrm{~mL} \mathrm{~min}^{-1}$ & 0.5 & 0.25 & $100.12 \pm 0.02$ & $100.18 \pm 0.07$ \\
\hline \multirow{2}{*}{ Organic (\%) in mobile phase } & 68.7 & 0.5 & 0.25 & $99.95 \pm 0.22$ & $100.15 \pm 0.04$ \\
\hline & 71.3 & 0.5 & 0.25 & $99.75 \pm 0.51$ & $100.18 \pm 0.07$ \\
\hline \multirow{2}{*}{ Detector wavelength } & $252 \mathrm{~nm}$ & 0.5 & 0.25 & $100.00 \pm 0.15$ & $99.81 \pm 0.19$ \\
\hline & $256 \mathrm{~nm}$ & 0.5 & 0.25 & $100.00 \pm 0.11$ & $99.53 \pm 0.37$ \\
\hline \multirow{2}{*}{ Column Temperature } & $39^{\circ} \mathrm{C}$ & 0.5 & 0.25 & $100.17 \pm 0.20$ & $100.08 \pm 0.11$ \\
\hline & $35^{\circ} \mathrm{C}$ & 0.5 & 0.25 & $100.41 \pm 0.46$ & $100.07 \pm 0.05$ \\
\hline
\end{tabular}

${ }^{*}$ Mean of three replicates.

satisfactory (Table 8 ). The mean recovery and \%RSD of analyzed sample indicate that the current method is robust.

\section{Conclusion}

The developed RP-HPLC method for the simultaneous determination of pyridoxine hydrochloride and meclizine hydrochloride is simple, precise, accurate, reproducible and highly sensitive. The developed method was validated based on ICH guidelines [21]. Hence, this method can be routinely used for the simultaneous determination of pyridoxine hydrochloride and meclizine hydrochloride in pure and pharmaceutical formulations.

\section{Conflict of Interests}

The author wishes to confirm that there is no known conflict of interests associated with this paper. The author confirms that he/she has given due consideration to the protection of intellectual property associated with this work and that there is no impediment to publication, including the trademarks mentioned in my paper.

\section{Acknowledgment}

The author is grateful to ACI Limited, Narayanganj, Bangladesh, for providing all kinds of financial and technical support to conduct this research work.

\section{References}

[1] A. Pathak and S. J. Rajput, "Simultaneous derivative spectrophotometric analysis of doxylamine succinate, pyridoxine hydrochloride and folic acid in combined dosage forms," The
Indian Journal of Pharmaceutical Sciences, vol. 70, no. 4, pp. 513517, 2008.

[2] J. E. Reynolds, The Extra Pharmacopoeia, Martindale, The Pharmaceutical Press, London, UK, 1996.

[3] Indian Pharmacopoeia, vol. 2, Government of India, The Controller of Publications, New Delhi, India, 1996.

[4] British Pharmacopoeia, vol. 3, British Pharmacopoeia Commission, The Stationery Office, London, UK, 2012.

[5] British Pharmacopoeia, vol. 2, British Pharmacopoeia Commission, The Stationery Office, London, UK, 2012.

[6] The United States Pharmacopoeia, 35, NF 30, vol. 3, United States Pharmacopeial Convention, Rockville, Md, USA, 2011.

[7] M. S. Arayne, N. Sultana, F. A. Siddiqui, M. H. Zuberi, and A. Z. Mirza, "Spectrophotometric methods for the simultaneous analysis of meclezine hydrochloride and pyridoxine hydrochloride in bulk drug and pharmaceutical formulations," Pakistan journal of pharmaceutical sciences, vol. 20, no. 2, pp. 149-156, 2007.

[8] H. H. Abdine, A. A. Gazy, and M. H. Abdel-Hay, "Simultaneous determination of melatonin-pyridoxine combination in tablets by zero-crossing derivative spectrophotometry and spectrofluorimetry," Journal of Pharmaceutical and Biomedical Analysis, vol. 17, no. 3, pp. 379-386, 1998.

[9] S. B. Bari and S. G. Kashedikar, "Simultaneous estimation of meclozine hydrochloride and nicotinic acid in combined dosage form by spectrophotometry," Indian Drugs, vol. 33, no. 8, pp. 411-414, 1996.

[10] J. G. Portela, A. C. S. Costa, and L. S. G. Teixeira, "Determination of Vitamin $B_{6}$ in pharmaceutical formulations by flow injection-solid phase spectrophotometry," Journal of Pharmaceutical and Biomedical Analysis, vol. 34, no. 3, pp. 543-549, 2004.

[11] C. S. Suresh, C. S. Satish, R. C. Saxena, and K. T. Santosh, "Simultaneous spectrophotometric analysis of a ternarymixture 
of pharmaceuticals-assay for meclozine hydrochloride, pyridoxine hydrochloride and caffeine," Journal of Pharmaceutical and Biomedical Analysis, vol. 7, no. 3, pp. 321-327, 1989.

[12] S. B. Bari and S. G. Kaskhedikar, "Simultaneous estimation of meclozine hydrochloride and caffeine in solid dosage form by employing multicomponent and derivative spectrophotometry," Indian Drugs, vol. 34, no. 2, pp. 85-88, 1997.

[13] B. Habibi, H. Phezhhan, and M. H. Pournaghi-Azar, "Voltammetric determination of vitamin $\mathrm{B}_{6}$ (pyridoxine) using multi wall carbon nanotube modified carbon-ceramic electrode," Journal of the Iranian Chemical Society, vol. 7, supplement, pp. S103-S112, 2010.

[14] A. P. Argekar and J. G. Sawant, "Simultaneous determination of pyridoxine hydrochloride and doxylamine succinate from tablets by ion pair reversed-phase high-performance liquid chromatography (RP-HPLC)," Drug Development and Industrial Pharmacy, vol. 25, no. 8, pp. 945-950, 1999.

[15] E. S. Tee and S. C. Khor, "Simultaneous determination of Bvitamins and ascorbic acid in multi-vitamin preparations by reversed-phase HPLC, Malaysian Journal of Nutrition, vol. 2, no. 2, pp. 176-194, 1996.

[16] M. S. Arayne, N. Sultana, and F. A. Siddiqui, "Simultaneous determination of pyridoxine, meclizine and buclizine in dosage formulations and human serum by RP-LC," Chromatographia, vol. 67, no. 11-12, pp. 941-945, 2008.

[17] M. E. Capella-Peiró, A. Bossi, and J. Esteve-Romero, "Optimization by factorial design of a capillary zone electrophoresis method for the simultaneous separation of antihistamines," Analytical Biochemistry, vol. 352, no. 1, pp. 41-49, 2006.

[18] C. K. Wong, J. R. Urbigkit, and N. Conca, "GLC determination of meclizine hydrochloride in tablet formulations," Journal of Pharmaceutical Sciences, vol. 62, no. 8, pp. 1340-1342, 1973.

[19] A. P. Argekar and J. G. Sawant, "Simultaneous determination of pyridoxine hydrochloride and doxylamine succinate in tablets by HPTLC," Journal of Liquid Chromatography and Related Technologies, vol. 22, no. 13, pp. 2051-2060, 1999.

[20] D. Widiretnani, S. I. Wahyuni, F. Kartinasari, and G. Indrayanto, "Simultaneous determination of pyrathiazine theoclate and pyridoxine $\mathrm{HCl}$ by TLC-densitometry in commercial tablets: validation of the method," Journal of Liquid Chromatography and Related Technologies, vol. 32, no. 1, pp. 154-165, 2009.

[21] ICH, Validation of Analytical Procedures: Text and Methodology Q2 (R1), Geneva, Switzerland, 1996. 

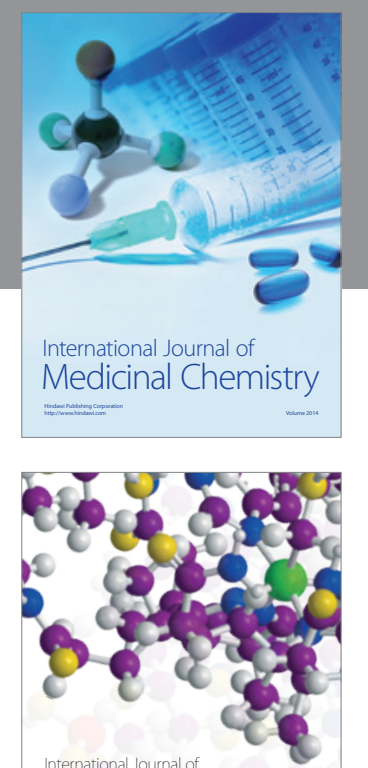

\section{Carbohydrate} Chemistry

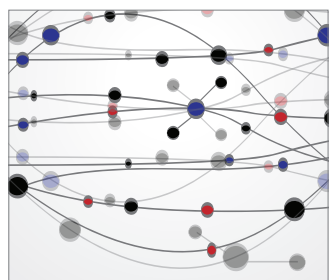

The Scientific World Journal
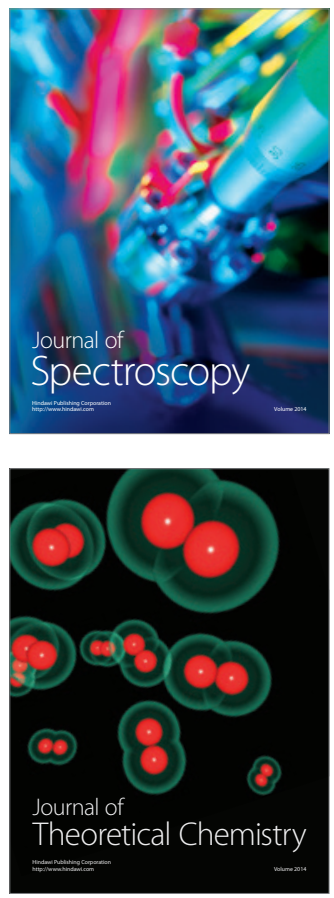
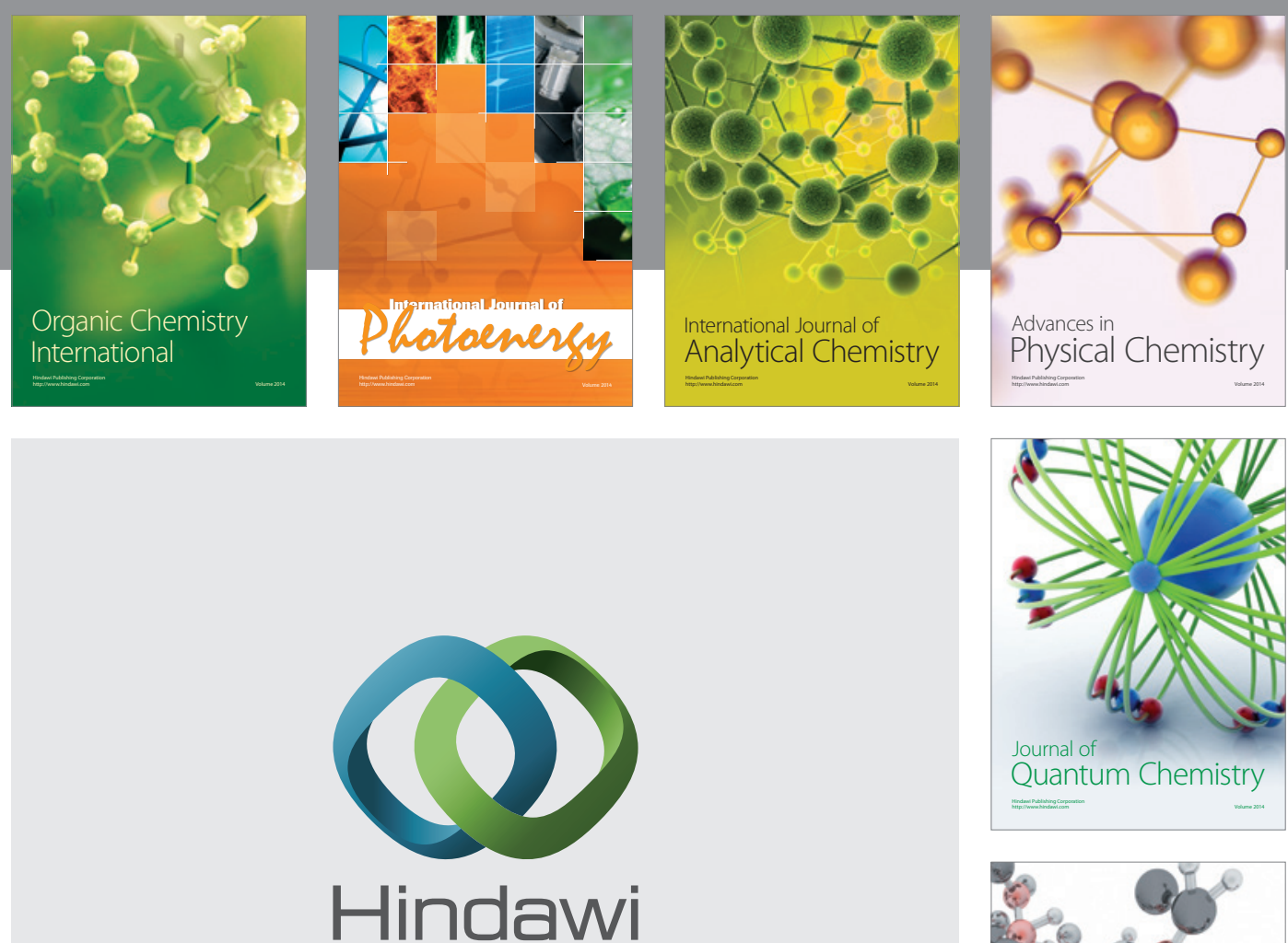

Submit your manuscripts at

http://www.hindawi.com

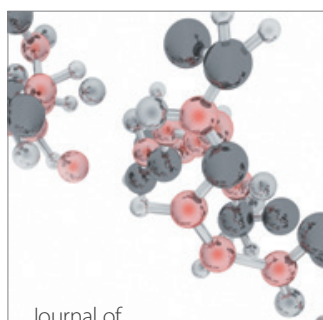

Analytical Methods

in Chemistry

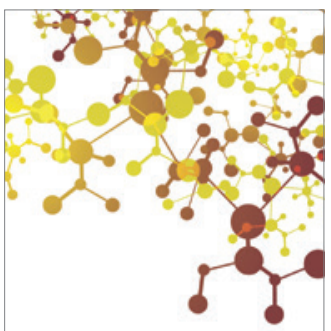

Journal of

Applied Chemistry

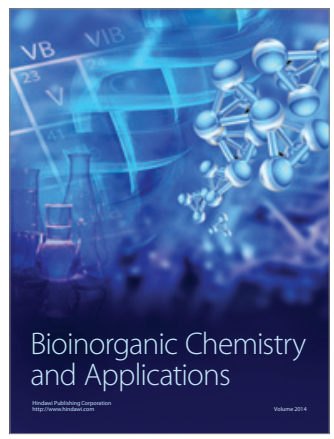

Inorganic Chemistry
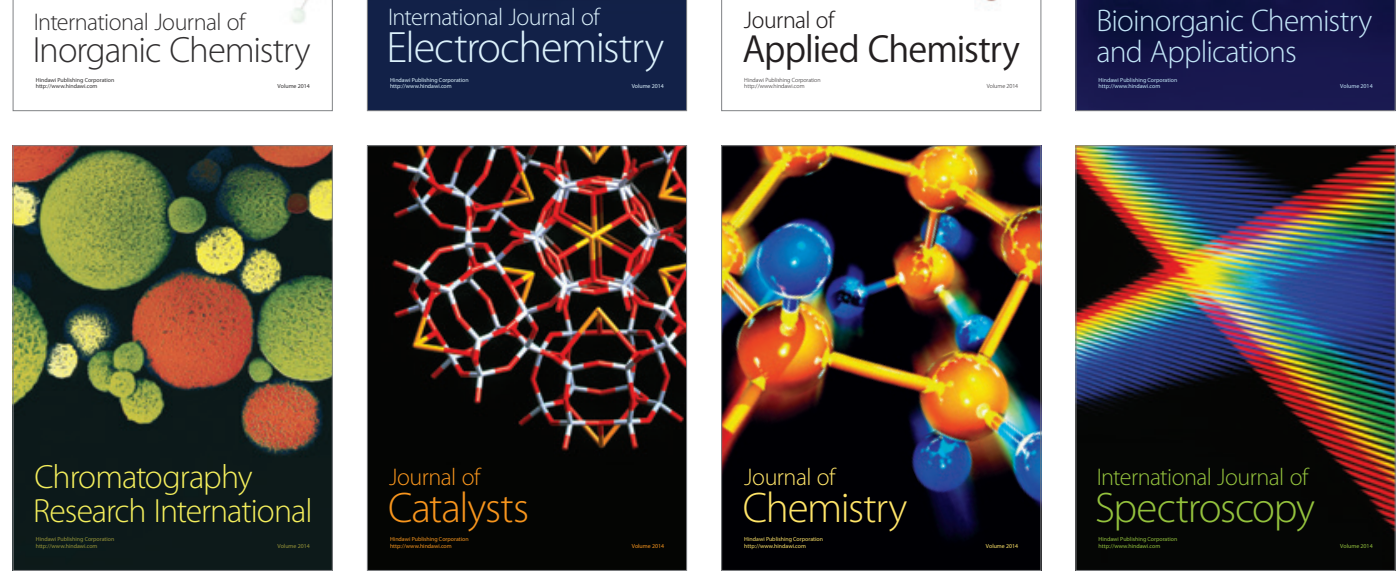